\title{
Islamic Harmony Examplar: the Qur'an's Frame on Social Interaction with Non-Muslims
}

\section{Ilham ${ }^{1}$, Muhammad Majdy Amiruddin'2, \& Arifuddin ${ }^{3}$}

${ }^{13}$ Institut Agama Islam Negeri Palopo, ${ }^{2}$ IAIN Parepare

e-mail: 1 m.ilham@iainpalopo.ac.id, ${ }^{2}$ muhammadmajdyamiruddin@iainpare.ac.id, 3arifuddin@iainpalopo.ac.id

\begin{abstract}
The actual dynamic authenticity of social life often shows accusations that religion is a source of social friction, violence, or conflict. The spirit of the Al-Qur'an shows an appreciative attitude, even inviting to the meeting point (common platform) of monotheism (tauhid) which is the basic teaching of the Torah, the Bible, and the Koran. This paper aims to explore the existence of non-Muslims from the perspective of the Al-Qur'an, the variants, and principles of social harmony with them. This paper uses qualitative as a method and literature as an approach. From the perspective of the Al-Qur'an, there are 3 variants of arranged interactions. First, in trade relations, second in marital relations, and third in political relations. The three variants of interaction must be based on the principle of Ihsan (good behavior) and Adalah (fair). Implications of this research present the idea of a meeting point between religions. This meeting point is expected to eliminate the friction of exclusivity between religious communities to create harmony and peace.
\end{abstract}

Keywords: Peace, Harmony, social interaction, non-muslim, Al Quran, Moderation

\begin{abstract}
Abstrak
Realitas kehidupan sosial yang sangat dinamis kerapkali menunjukkan tudingan seolah-olah agama menjadi sumber gesekan sosial, kekerasan ataupun konflik. Semangat al-Qur'an menunjukkan sikap apresiatif, bahkan mengajak menuju kepada titik pertemuan (common platform) monoteisme (tauhid) yang merupakan ajaran dasar Taurat, Injil, dan al-Qur'an. tulisan ini mengeksplorasi eksistensi non muslim perspektif al-Qur'an, varian dan prinsip harmoni sosial dengan mereka. Tulisan ini menggunakan qualitatif sebagai metodenya dan pustaka sebagai pendekataannya. Dalam persepektif Al Quran, ada 3 varian interaksi yang diatur. Pertama dalam hubungan perdagangan, kedua dalam hubungan pernikahan dan ketiga dalam hubungan politik. Ketiga varian interaksi tersebut harus
\end{abstract}


dilandasi oleh prinsip ihsan (berlaku baik) dan adalah (berlaku adil). Implikasi dari Penelitian ini menghadirkan gagasan tentang titik temu antar-agama. Titik temu inilah yang diharapkan mampu menghilangkan gesekan ekslusivitas antar umat beragama sehingga tercipta harmoni dan kedamaian.

Kata Kunci: Damai, Harmoni, Interaksi Sosial, Non-muslim, Al Quran, Moderasi

\section{INTRODUCTION}

In current world advance, globalization can be denoted as an era of a world without boundaries. The transportation and communication technology revolution has amplified the flow of people, goods, services, and information across national borders (Cuervo-Cazurra, Doz, \& Gaur, 2020). A side symptom of this current globalization is the surge of conflict, both at the global, national, and local levels. People derive into contact and discovery differences that can easily be translated into differences in interests and alterations in strength, also people tend to look for their identity in certain groups, with certain mutual symbols, identical interests, and shared values. Therefore, diversity appears which results in interactions and actions of knowing each other and being tolerable, even knowing and rejecting each other (Poli, 2005).

According to Fracoise, One of the trajectories of social interaction is the relationship between religious communities. Tracing religious guidance related to social interactions with non-Muslims is very important. This is based on an assumption that as long as humans still believe in religion as a way of life or a source of truth and moral strength under divine values, they always refer to and need religion in every problem they face (Francoise, 2017).

Kanu believed that Religion is the carrier of humanistic-transcendental values such as peace, harmony, justice, and equality by its adherents. However, this charming ideal does not always correspond to social logic. Religion on the one hand teaches goodness and peace, but on the other hand, it is often claimed to be a trigger for social friction and conflict (Kanu, 2019).

An addition from Winegar, there is no single religion that instructs its followers to conflict or commit acts of violence because religion explicitly teaches about peace. However, the very dynamic reality of social life often shows accusations that religion is a source of social friction, violence, or conflict (Winegar, 2008). 
Hamim also stated that every religion, especially Islam teaches peace, togetherness and at the same time spreads a mission to benefit the surrounding environment. However, at the sociological level, the face of religion is not as ideal as expected in this normative framework. Often the face of religion appears as a frightening specter, tarnished by the behavior of some of its adherents because sometimes they interpret normative theological teachings carelessly and blindly (Hamim, 2007).

Although in numerous verses, the Koran is critical and corrective towards followers of other religions (non-Muslims), the spirit of the Koran shows an appreciative attitude, even inviting them to the common platform of monotheism (tauhid) which is also included in of the Torah, the Bible, and the Koran. Therefore, it is natural for Islam to respond to the existence of religions that were already present and the apostle was one of Allah's messengers who were sent to this world (Munawar-Rachman, 2010).

This paper presents an exemplar of the principle of Islamic harmony in the context of diversity by framing the principles of the Koran regarding social interactions with non-Muslims. Specifically, this paper explores the existence of interaction models toward non-Muslims in the perspective of the Qur'an, the variants, and principles of social harmony with non-Muslims from the perspective of the Qur'an.

\section{RESEARCH METHOD}

This paper is a literature research with various interpretive books as a source of study. The research begins by identifying the existence of non-Muslims in the Koran using Text Structure Analysis by Van Dijk. To examine the structure of the text, the texts will be divided into three structures or levels, each of which supports each other. First, the macro structure (thematic), which is the global meaning of a text which can be seen from the topic or theme that is highlighted in a text. Second, superstructure (schematic), namely the structure of discourse related to the framework of a text. Third, the micro structure (semantics), which is the meaning of a discourse that can be observed through small parts of a text, such as words, sentences, propositions, clauses, paraphrases, and language styles used by a text. After that, the resulting groupings will be analyzed according to the harmony principle. 


\section{RESEARCH FINDINGS AND DISCUSSION}

\section{Macro Structure Analyses: Social Interaction toward Non-Muslim in Al-Qur'an}

Social interaction means dynamic social relationships between individuals and between groups. If non-Muslims are interpreted as people who are not followers of the Islamic religion, then the term in the al-Qur'an is equivalent to the term "Ahl al-Kitab"(Mardan, 2012).

The term is series of two words, explicitly أهل which is a plural lafaz that is equivalent to the word fi'lun, and al-kitab (Al-Suyuti \& bin Abi Bakar, 2000). The word ahl is definited in the Qur'an 125 times, with various uses. The word ahl which refers to a certain group such as ahl al-bayt (the Prophet's family) can be found, for example, in QS al-Ahzab/33:33 explain that "And abide in your houses and do not display yourselves as [was] the display of the former times of ignorance. And establish prayer and give zakat and obey Allah and His Messenger. Allah intends only to remove from you the impurity [of sin], O people of the [Prophet's] household, and to purify you with [extensive] purification."

The word ahl in the al-Qur'an can also refer to the meaning of the population. As seen in QS al-Qashash/28: 45 explain that "But We produced [many] generations [after Moses], and prolonged was their duration. And you were not a resident among the people of Madyan, reciting to them Our verses, but We were senders [of this message]."

The word ahl is also expressed in the Qur'an with the meaning of family. As contained in QS al-Nisa'/4: 35 explain that "And if you fear dissension between the two, send an arbitrator from his people and an arbitrator from her people. If they both desire reconciliation, Allah will cause it between them. Indeed, Allah is ever Knowing and Acquainted [with all things]."

Referring to the meaning of a certain group, the word ahl also sometimes refers to the meaning of followers of certain ideologies or owners of certain teachings, as what is contained in QS al-Baqarah/2: 105explain that "Neither those who disbelieve from the People of the Scripture nor the polytheists wish that any good should be sent down to you from your Lord. But Allah selects for His mercy whom He wills, and Allah is the possessor of great bounty."

Likewise, the term al-Kitab is also mentioned in the Koran 319 times with various meanings. The term ahl al-Kitab which was directly articulated was 31 
times and spread in 9 chapters, namely 8 chapters including Madaniyah and one Makkiyah surah, namely QS al-`Ankabut/29:46 (Umar, 2008).

The term ahl al-Kitab generally means those who get al-Kitab, namely those who are united by the divine book(Umar, 2008), although usually addressed to Jews and Christians (Umar, 2008) which is interpreted as adherents of divine religious books.

Even though in many verses, the Koran is critical and corrective towards ahl al-Kita b, in fact, the spirit of the Koran shows an appreciative attitude, even inviting them to the common platform of monotheism (tauhid). are the basic teachings of the Torah, the Bible, and the Koran (Fynn-Paul, 2017). Therefore, it is natural for Islam to respond to the existence of religions that were already present and the apostle was one of Allah's messengers who were sent to this world (Munawar-Rachman, 2010).

Even so, the term ahl al-Kitab which is textually continually mentioned in the al-Qur'an reaps various understandings in defining who is meant by ahl alKitab by al-Qur'an. Some interpret it as (1) a community that has divine scriptures, (2) a Jewish and Christian community of Israeli descent, as perceived by Imam Syafi'i, or without distinguishing where their descendants come from, (3) other than the Jewish community and Christians, as well as the Magi, as understood by Ibn Hazm, and some even classify Hinduism, Buddhism, Kong Fu tse, Shinto and the like, as understood by Maulana Muhammad Ali and Rasyid Ridha (Gusmian, 2013).

Following are the verses in the al-Qur'an related to social interactions with non-Muslims:

1. QS al-Baqarah/2: 105 and 109 (Makkiyah). For example in surah al-Baqarah verse 105 to comfirms that neither those who disbelieve from the People of the Scripture nor the polytheists whis that any good should be sent down to you from your Lord. But Allah selects for His mercy whom He wills, and Allah is the possessor of great bounty.

2. QS Ali Imran/3: 64, 65, 69, 70, 71, 72,75, 98, 99, 110, 113, 199Makkiyah. For examples in surah Ali Imran verse 64 to confirms that say, O People of the Scripture, come to a word that is equitable between us and you. That we will not worship except Allah and not associate anything with Him and not take 
one another as lords instead of Allah. But if they turn away, then say, Bear witness that we are Muslims (submitting to Him).

3. QS al-Nisa'/4:123, 153, 159, and 171 (Makkiyah). For example in surah alNisa' verses 123 to confirms that paradise is not (obtained) by your wishful thinking nor by that of the People of the Scripture. Whoever does a wrong will be recompensed for it, and he will not find besides Allah a protector or helper.

4. QS al-Maidah/5: 15, 19, 59, 65, 68, and 77 (Makkiyah). For example in surah al-Maidah verse 15 to confirms that day (all) good foods have been made lawful, and the food of those who were given the Scripture is lawful for you and your food is lawful for them. And (lawful in marriage are) chaste women ftom among those who were given the Scripture before you, when you have given them their due compensation, desiring charity, not lawful sexual intercourse or taking (secret) loves. And whoever denies the faith his work has become worthless, and he in the hereafter will be among the losers.

5. QS al-'Ankabut/29: 46 (Madaniyyah) to confirms that and do not argue with the People of the scripture except in a way that is best, except for those who commit in justice among them and say "We believe in that which has been revealed to us and revealed to you. And our God and your God is one, and we are Muslims (in submission) to Him."

6. QS. al-Ahzab/33:26 to confirms that and he brought down those who supported them among the People of the Scripture from their fortresses and cast terror into their hearts (so that) a party you killed, and you took captive a party.

7. QS Al-Hadid/57: 29 to confirms that this is so that People of the Scripture may know that they are not able (to obtain) anything from the bounty of Allah and that (all) bounty is in the hand of Allah. He gives it to whom $\mathrm{He}$ wills. And Allah is the possessor of great bounty.

8. QS. Al-Hasyr/59: 2 and 11. For example in surah al-Hasyr verse 2 to confirms that its He who expelled the ones who disbelieved among the People of the Scripture from their homes at the first gathering. You did not think they would leave and they thought that their fortresses would protect them from 
where they had not expected, and He cast terror their (own) hands and the hands of the believers. So take warning $\mathrm{O}$ people of vision.

9. QS. Al-Bayyinah/98: 1 and 6. For example in surah al-Bayyinah verse 1 to confirms that those who disbelieved among the People of the Scripture and the polytheists were not to be parted (from misbelieve) until there came to them clear evidence.

The terms used by the Koran have the same meaning as ahl al-Kitab, namely allazi na ataina hum al-kitab, allazina utu al-kitab, allazina utu nashiban min al-kitab and allazina yaqra'una al-kitab. The phrase allazina ataina hum al-kitab is mentioned 9 times, allazi na utu al-Kitab in the Al-Qur'an 21 times, allaziutu nashiban min al-Kitab repeated 32 times, and allazina yaqra'una al-kitab min qablik 1 time (Munawar-Rachman, 2010).

\section{The Variant of Social Interaction with Non-Muslim: a Schematic Analyses}

Among the verses that describe the basic principles of social interaction with non-Muslims are QS al-Ma'idah/5:5, QS al-Baqarah/2:221, and QS al-Taubah/9:29

\section{Validity of the Food Exchange}

In the QS al-Ma'idah/5:5 explain that this day [all] good foods have been made lawful, and the food of those who were given the Scripture is lawful for you and your food is lawful for them. The phrase tha'am in the verse is the basic meaning of "food". In the context of this verse, it means slaughter, because of the previous verse (QS al-Ma'idah/5: 3) It has been confirmed that the things that are prohibited are prohibited so that apart from them are automatically halal. This understanding is also supported by QS al-Ma'idah / 5: 4 which describes slaughtering and hunting, so that these two things are the main problem (Mohamad \& Khairuldin, 2018).

One opinion also mentions that word tha'am, also means food in a more specific sense, namely fruits, seeds, and the like. This does not mean that every food they serve has mixed with things that are forbidden in Islam, such as lard or liquor, or because things are considered unclean (Prasetiyo, 2020).

The phrase allazina utu al-kitab which means those who were given alKitab. While the phrase wa tha'amukum hillun lahunna (and your food), is an 
emphasis that in the case of food reciprocal activities and exchanging food are justified, but in the case of marriage this is not justified.

Thus, the content of the verse explains the relationship between social interactions in the context of food (slaughter) with non-Muslims. Textually, this verse illustrates that the food slaughtered by ahl al-Kitab is halal eaten by Muslims and vice versa (Mardan, 2012).

\section{Marriage Organization}

QS al-Ma'idah/5:5 explain that and [lawful in marriage are] chaste women from among the believers and chaste women from among those who were given the Scripture before you, when you have given them their due compensation, desiring chastity, not unlawful sexual intercourse or taking [secret] lovers. And whoever denies the faith - his work has become worthless, and he, in the Hereafter, will be among the losers."

And also QS al-Baqarah/2:221 to explain that "And do not marry polytheistic women until they believe. And a believing slave woman is better than a polytheist, even though she might please you. And do not marry polytheistic men [to your women] until they believe. And a believing slave is better than a polytheist, even though he might please you. Those invite [you] to the Fire, but Allah invites to Paradise and to forgiveness, by His permission. And He makes clear His verses to the people that perhaps they may remember."

The phrase wa al-muhshanat (women who maintain honor) is a sign that those who should be married are women who maintain their honor, both women who believe and ahl al-Kita. The mention of women of faith is a sign that they should come first, because after all, the equality of religion and way of life has an impact on tranquility, and even greatly determines the sustainability of the household (Ghazali, 2005).

The phrase syirk (ascribing a partner or rival to Allaah in Lordship). In a religious perspective, a person is said to be idolatrous if he believes that there is a God other than Allah, or an activity that has a dual main purpose, first to Allah, and second to other than Him (Ahmad, 2017).

The scholars of al-Qur'an have other views on this matter. According to them, the word musyrik is used in the Qur'an for certain groups who associate 
Allah. They are idolaters. They were still in this activity when the Qur'an was revealed. Especially those who resided in Mecca (Mardan, 2012).

This verse is a sign of the permissibility of a Muslim man to marry the woman ahl al-Kitab. However, the scholars differ on this matter. The first group, which is the majority of scholars, believes that it is lawful to marry a woman ahl al-Kitab. The arguments put forward are (1) based on QS al-Ma'idah/5: 5 which explains that marrying ahl al-Kitab is a lawful matter, (2) historical facts show that some of the Prophet's companions had married women ahl al-Kitab, such as: Usman ibn Affan, Thalhah, Zubair. The second group believes that marrying a woman ahl al-Kitab is haram. This group was represented by the Prophet's friend, Ibn Umar. The argument is (1) based on QS al-Baqarah / 2: 221 which confirms wa la tunkihu al-musyrikat hatta yu'minna (2) based on QS alMumtahanah/60: 10, wa la tumsiku bi 'ishami al-kawafir (Muslim women are not halal for unbelievers, and infidels are also not halal for them).

According to the second group, ahl al-Kitab belongs to the polytheist group, because the Jews deify 'Uzair and the Christians deify Isa Ibn Maryam. In this case, the sin of shirk does not get forgiveness if they do not repent to Allah before they die (QS al-Nisa'/4: 116).

Conserning wa al-muhshanat min allazina utu al-kitab min qablikum it should be interpreted as permissible to marry ahl al-Kitab if the number of Muslim women is few, or those who adhere to Judaism and Christianity before Muhammad was appointed as an apostle (Ghazali, 2005).

QS al-Ma'idah / 5: 5 is then closed with a threat that those who disbelieve after believing will erase their practice. This verse is a warning to anyone who wants to eat something or is planning a marriage with / or from them, so be careful not to let it lead to kufr which results in torment in the hereafter (Mardan, 2012).

\section{Political Matter}

QS al-Taubah/9: 29 to explain that fight those who do not believe in Allah or in the Last Day and who do not consider unlawful what Allah and His Messenger have made unlawful and who do not adopt the religion of truth from those who were given the Scripture - [fight] until they give the jizyah willingly while they are humbled. 


\section{Fitrah}

Jurnal Kajian Ilmu-ilmu Keislaman

Vol. 6 No. 2 December 2020

The context that accompanies the presence of this verse is when Christians and Jews gather to attack Muslims, but the plan is known to Muslims. This information was obtained from traders who came from Syria (Damascus), that the vanguard of their troops was already in Balqa '(Jordan). In this regard, this verse came down as an order to put up resistance against them. Even the commentators say that this verse is the first verse to come down in connection with the command to fight against ahl al-Kitab.The phrase al-jizyah is a formation of the root word jaza which means to fulfill, fulfill, and repay. Al-jizyah it is only mentioned once in the Qur'an (QS al-Taubah/9: 29). Jizyah is a reward or reward for the sense of security and facilities obtained by non-Muslims in an Islamic state(Naskur, 2016).

The word 'an yadin means by hand. When the word is juxtaposed with the jizyah giver, the series means submitting and obeying or paying cash and not delaying it.

The phrase wa la yuharrimuna ma harramallahu wa rasuluhu gives an understanding that Christians do not prohibit pigs and Jews do not proscribe non-Jews and wa hum shagirun is undestood as compliance with legal provisions.

Thus, jizyah is a head tax issued by ahl al-Kitab who is under the protection of the security of Islamic territory. This does not mean that nonMuslims are class II citizens. The jizyah which is applied to them is almost the same as zakat, as it applied to Muslims. In this case, jizyah is not a religious tax, because that definition is against the spirit of Islam. Before the arrival of Islam, taxes were practiced by both Islamic and non-Muslim countries. The main objective of this tax is to maintain the welfare of the people in a country. The obligation to pay jizyah at the time of the Holy Prophet was only borne by men who were capable and conditioned according to the objective socio-economic conditions of the non-Muslim group (Mardan, 2012).

Thus, it can be seen that the concept of the al-Qur'an regarding social interaction with non-Muslims is a response to plural religious realities on the one hand, and the affirmation of the theological identity of Islam on the other.

\section{Semantic Analyses: Basic Principles of Social Harmony toward non-Muslim}

Among the verses that describe the basic principles of social interaction with non-Muslims are QS al-Mumtahanah/60:8-9 to explain that Allah does not forbid you from those who do not fight you because of religion and do not expel 
you from your homes - from being righteous toward them and acting justly toward them. Indeed, Allah loves those who act justly.

Allah only forbids you from those who fight you because of religion and expel you from your homes and aid in your expulsion - [forbids] that you make allies of them. And whoever makes allies of them, then it is those who are the wrongdoers.

The context that accompanies the passage of the verse is when Qutillah, the mother of Asma' 'bint Abu Bakr, who is a musyrikah, wants to visit with a gift to her child (Asma'), but Asma 'does not allow her to enter and is reluctant to accept her mother's gift. He then asked 'Aisyah until the verse came down and the Prophet ordered him to entertain and accept the gift (HR. al-Hakim Abu' Abdillah).

Another narration states that Asma bint Abu Bakr told that her mother - a musyrikah - visited her, then she met the Prophet and asked: "can I have a relationship with my mother?" The Holy Prophet replied: "Yes, establish a good relationship with him"(Shabuni, 1996).

The phrase lam yuqatilukum fi al-din wa lam yukhrijukum min diyarikum provide an understanding that they do not fight and do not expel Muslims from their country. Therefore, as long as it does not have a negative effect, doing good to non-Muslims is not a forbidden thing in religion. Allah swt through the alQur'an permitted to be kind to them by saying an tabarruhum wa tuqsthu ilaihim.

The phrase tabarruhum is a formation of words birrun hat have meaning virtue wide. While the word tuqsithu $\mathrm{s}$ a derivation of the word al-qisth that meaning fullfair or part. Then Allah swt closed the verse by saying that in fact He really likes people who are fair innallah yuhibbul muqsithin. This shows that doing good deeds and giving part of the wealth to non-Muslims is a form of noble deeds with Allah (Mardan, 2012).

The commentator categorizes verse 8 of surah al-Mumtah\} anah as rukhsah to the first verse of the surah. However, both verses (verses 8 and 9) imply two kinds of enemy groups with different methods of interaction.

The first group, those who do not fight in matters of religion and do not expel Muslims from their country. Therefore, Allah Almighty confirms with His Word la yanhakumullah dan an tabarruhum wa tuqsithu ilaihim. 


\section{Fitrah \\ Jurnal Kajian Ilmu-ilmu Keislaman \\ Vol. 6 No. 2 December 2020}

The second group, those who fought and expelled Muslims from their country, or took part in the expulsion. Therefore, Allah swt innama yanhakumullah dan an tawallawhum.

Based on this verse, it can be seen that there are two groups of ahl al-Kitab and their interaction models are also different. However, al-Syanqithy considers that the classification does not interfere with the generality of QS alMumtahanah/60: 1 the meaning of "O you who have believed, do not take My enemies and your enemies as allies, extending to them affection while they have disbelieved in what came to you of the truth, having driven out the Prophet and yourselves [only] because you believe in Allah, your Lord. If you have come out for jihad in My cause and seeking means to My approval, [take them not as friends]. You confide to them affection, but I am most knowing of what you have concealed and what you have declared. And whoever does it among you has certainly strayed from the soundness of the way."

The two previous verses (QS al-Mumtahanah/60: 8-9), according to some commentators are rukhsah to Muslims for the previous prohibition on QS alMumtahanah/60: 1. However, this verse (QS al -Mumtahanah/60: 8-9) then republished by the verse of war (Rohman, 2013)

Imam al-Suyuthy, when interpreting the verse, mentioned the narration of Ibn Munzir from Mujahid which states that the meaning of the verse is addressed to the unbelievers of Mecca. Another narration also states that the verse was annulled by QS al-Taubah/ 9: 5, which ordered to fight against ahl alKitab (Al-Suyuti \& bin Abi Bakar, 2000).

And when the sacred months have passed, then kill the polytheists wherever you find them and capture them and besiege them and sit in wait for them at every place of ambush. But if they should repent, establish prayer, and give zakah, let them [go] on their way. Indeed, Allah is Forgiving and Merciful (QS al-Taubah / 9: 5).

Regardless of the ulama's view of the verse, both are verses that regulate social interactions with non-Muslims. This verse emphasizes the values of justice even for non-Muslims. The Qur'an does not make religious differences an excuse for not having a cooperative relationship, let alone adopting an unfriendly attitude. The Qur'an in no way prohibits a Muslim from doing good and giving even part of his property to anyone, as long as they do not fight against Muslims for religious motives or expel Muslims from their country. Therefore, religion is 
not a barrier to building social interactions with non-Muslims, as long as these social interactions are within the frame of truth(Mardan, 2012). On the contrary, being kind and gentle is a reward and reciprocity for their attitude which is not hostile to and against Muslims(al-Zamakhsyari \& Ibn`Umar, 2010).

Islam advises that the relationship between humans is a bond of brotherhood. Treatment of others as brothers is a religious command. Every human being comes from one mother and one father. Every human being needs to be appreciated. Therefore, the Holy Prophet taught that brotherhood demands harmonious relations and affection "visit and exchange gifts". Therefore, Islam does not prohibit giving and receiving gifts to and from anyone, as long as it does not cloud the creed. The Holy Prophet himself received a gift from the Christian ruler of Egypt in the form of a girl named Mariah, from whom his son Ibrahim was born.

The issue of visiting and exchanging gifts should not be related to faith and kufr, but the gift is based solely on a sense of brotherhood or humanity. Not upon you, [O Muhammad], is [responsibility for] their guidance, but Allah guides whom He wills... (QS al-Baqarah/2: 272).

Thus, Islam is a religion of peace and a creed of love. It is a divine system that aims to overshadow the entire universe with peace and love that can bring humans closer to Him (Mardan, 2012)

\section{CONCLUSION}

Harmony between religious communities cannot be realized when religious adherents still prioritize exclusivity. All religions have universal values that are sometimes ignored. In the Al Quran, universality in social interaction between religious communities is mentioned several times. Non-Muslims who are interpreted as people who are not followers of the Islamic religion find their equivalent in the Qur'an with the term ahl al-Kitab. is repeated 31 times in the Qur'an. Ahl al-Kitab in this case reaps different views among commentators. Some interpret it as (1) a community that has divine scriptures, (2) a Jewish and Christian community of Israeli descent or regardless of where their descent is, (3) besides the Jewish and Christian communities, also the Magi, Hinduism, Buddhism, Kong Fu tse, Shinto and the like are also categorized as ahl al-Kitab. Among the forms of social interaction universality with non-Muslims in the Qur'an includes 1) in terms of food; 2) in the case of marriage; 3) in terms of jizyah. The basic principle of social interaction with non-Muslims in the 


\section{Fitrah}

$\Rightarrow$ Jurnal Kajian Ilmu-ilmu Keislaman

Vol. 6 No. 2 December 2020

perspective of the Qur'an does not make religion a barrier that hinders the process of social interaction, as long as it leads to goodness.

As implication, Social interaction with non-Muslims as a concept contained in the Qur'an is very important to be understood and grounded in society. The meaning of this concept must always open up space for any meaning that can accommodate the spirit of the times as an effort to realize the dictum of al-Qur'an instead of li kulli zaman wa then (always in tune with the context of space and time). 


\section{REFERENCES}

Ahmad, A. (2017). Are they married? Muslim marriages and the interrelationship between transnationalism and ethnonationalism in the Gulf. Journal of Middle East Women's Studies, 13(1), 3-24.

Al-Suyuti, al-I. J. A., \& bin Abi Bakar, R. (2000). Dar al-Manthur fi al-tafsir alma'thur. Dar Al-Kutub Al-Ilmiah, Beirut: Lubnan, 1.

al-Zamakhsyârî, A. al-Q. J., \& ibn'Umar, M. (2010). al-Kasysyaf 'an Haqaiq alTanzil wa 'Uyun al-Aqawil fi Wujuh al-Ta'wil. Juz I. Beirût: Dâr Al-Kutub Al'Ilmiyyah, 1415.

Cuervo-Cazurra, A., Doz, Y., \& Gaur, A. (2020). Skepticism of globalization and global strategy: Increasing regulations and countervailing strategies. Global Strategy Journal, 10(1), 3-31.

Francoise, J. (2017). Pemikiran Politik Islam Modern: Peran Majelis Ulama Indonesia. The 1st UICIHSS (International Conference on Islamic Humanities and Social Sciences).

Fynn-Paul, J. (2017). Empire, monotheism and slavery in the greater Mediterranean region from antiquity to the early modern era. In Critical Readings on Global Slavery (pp. 553-587). Brill.

Ghazali, A. M. (2005). Tafsir Islam Progresif Tentang Nikah Beda Agama. Istiqro, $4(01), 225-249$.

Gusmian, I. (2013). Khazanah Tafsir Indonesia; dari Hermeneutika hingga Ideologi. LKIS PELANGI AKSARA.

Hamim, T. (2007). Resolusi Konflik Islam Indonesia. Kerjasama Lembaga Studi Agama dan Sosial (LSAS), IAIN Sunan Ampel, IAIN ....

Kanu, I. A. (2019). Igwebuike as an Igbo-African modality of peace and conflict resolution. Journal of African Traditional Religion and Philosophy, 1(1).

Mardan, M. (2012). Konsepsi al-Qur'an: Kajian Tematik atas Sejumlah Persoalan Masyarakat. Alauddin University Press.

Mohamad, N. S., \& Khairuldin, W. (2018). The concept of Halalan Tayyiba in food according to Mufassir. International Journal of Academic Research in Business and Social Sciences, 8(11), 902-909.

Munawar-Rachman, B. (2010). Argumen Islam untuk pluralisme. Grasindo. 
Vol. 6 No. 2 December 2020

Naskur, N. (2016). Hukum Islam dan Pranata Sosial (sebuah Kajian Makna Teks Nash). Jurnal Ilmiah Al-Syir'ah, 1(2).

Poli, W. I. M. (2005). Hubungan Antar Manusia dan Penanganan Konflik. Jurnal Jaffray, 1(1), 5-15.

Prasetiyo, J. R. (2020). The Role of Religion on Food Consuming Issue Developing Theological-Philosophy Concept of Food Through Al Qur'an. SHAHIH: Journal of Islamicate Multidisciplinary, 5(1), 1-14.

Rohman, I. (2013). Adwa'al-Bayan Karya al-Shanqiti Sebagai Kitab Tafsir alQur'an bi al-Qur'an. JOURNAL OF QUR'AN AND HADITH STUDIES, 2(2), 247-265.

Shabuni, M. A. (1996). Shafwat Al Tafasir. Kairo: Dar Al-Salam.

Umar, A. M. (2008). Mu'jam al-Lughah al-Arabiyyah al-Mu'ashiroh. Kairo:'Alam Al-Kutub.

Winegar, J. (2008). The humanity game: Art, Islam, and the war on terror. Anthropological Quarterly, 651-681. 